"Skorpion" i „Poza Układem". Przyczynek do historii trójmiejskiego
podziemia wydawniczego w latach
osiemdziesiątych XX wieku

\section{PIOTR BRZEZIŃSKI}

Instytut Pamięci Narodowej ORCID: 0000-0002-4623-9274

\section{Uwagi wstępne}

Podziemny ruch wydawniczy w czasach PRL cieszy się w ostatnich latach dużym zainteresowaniem badaczy ${ }^{1}$. Zasadniczym celem niniejszego artykułu jest ukazanie działalności wydawniczej grupy osób skupionej wokół Joanny i Andrzeja Gwiazdów, która w latach 1982-1983 tworzyła podziemne pismo "Skorpion", a następnie w latach 1984-1986 „Poza Układem”. Moim zamierzeniem jest zarówno odsłonięcie kulis powstania i działalności tych pism, jak też przybliżenie treści niektórych publikowanych na ich łamach tekstów.

„Poza Układem" ukazywało się dwukrotnie, w latach 1984-1986 i 1989-1997. W swojej analizie skupię się jednak wyłącznie na pierwszym etapie jego funkcjonowania, gdyż drugą edycję pisma uważam za temat wykraczający chronologicznie poza czasy PRL i już choćby z tego powodu wymagający odrębnego rozpatrywania. Historia "Skorpiona" $\mathrm{i}$ „Poza Układem” jest natomiast ze sobą ściśle związana, ponieważ zarówno w sensie personalnym, jak i programowym "Skorpion" był protoplastą „Poza Układem".

Podstawą źródłową niniejszego artykułu są zachowane w archiwach i bibliotekach egzemplarze obu pism², a także wywiady przeprowadzone z niektórymi osobami zaangażowanymi w ich powstawanie ${ }^{3}$. Prezentowany tekst jest pierwszym tego typu opracowaniem na ten temat i siłą rzeczy ma charakter jedynie przyczynkowy. Mimo

1. Zob. m.in.: J. Błażejowska, Pepierowa rewolucja. Z dziejów drugiego obiegu wydawniczego w Polsce 1976-1989/1990, Warszawa 2010; A. Fic, Drukarnia podziemna w Trójmieście w latach wojny jaruzelskopolskiej, Gdynia 2005; K. Knoch, Pisma liberalne w drugim obiegu w latach 1979-1990, Warszawa 2015; J. Olaszek, Rewolucja powielaczy. Niezależny ruch wydawniczy w Polsce 1976-1989, Warszawa 2015; idem, Podziemne dziennikarstwo. Funkcjonowanie głównych pism informacyjnych podziemnej "Solidarności" w Warszawie w latach 1981-1989, Warszawa 2018; W. Polak, Wydawnictwo Alternatywy. Z dziejów gdańskiej poligrafii podziemnej, Gdańsk-Toruń-Bydgoszcz 2009.

2. Udało mi się dotrzeć do trzech numerów „Skorpiona” i dziesięciu numerów pierwszej edycji „Poza Układem".

3. Wśród moich rozmówców znaleźli się: Stefan Adamski, Joanna Duda-Gwiazda, Andrzej Gwiazda, Magdalena Czachor, Marek Czachor i Karol Krementowski. Korzystając z okazji, bardzo dziękuję im za ciekawe rozmowy i cenne relacje. 
to mam nadzieję, że stanie się on inspiracją dla dalszych badań historycznych i kolejnym impulsem do podjęcia dyskusji na temat trójmiejskiego podziemia wydawniczego $\mathrm{z}$ lat osiemdziesiątych ${ }^{4}$.

\section{Od „Skorpiona” do „Poza Układem”}

Po wypuszczeniu na wolność z obozu internowania latem 1982 roku Joanna Duda-Gwiazda wpadła na pomysł wydawania podziemnego pisma. Jak wspominała: „W Gdańsku wydawanie własnego pisma było koniecznością, ponieważ, jeśli chodzi o prasę podziemną, był to region bardzo słaby. Wychodziło niewiele gazetek, a wszystkie, nawet zakładowe i bardzo dobre, jak np. «Portowiec», podporządkowane były RKK ${ }^{5}$, czyli [Bogdanowi] Borusewiczowi, [Aleksandrowi] Hallowi i [Bogdanowi] Lisowi. Po wyjściu z interny próbowałam negocjować jakąś współpracę z redakcją «Portowca», ale nie byli tym zainteresowani"6. Z uwagi na fakt, że Andrzej Gwiazda nadal przebywał w areszcie w Białołęce, a później - z krótką przerwą w drugiej połowie 1984 roku - był więziony w kolejnych miejscach odosobnienia aż do maja 1985, nie brał on osobiście udziału w tworzeniu „Skorpiona” i „Poza Układem”.

Najbliższym współpracownikiem Joanny Dudy-Gwiazdy był początkowo Marek Kubasiewicz, który wziął na siebie sprawy związane $\mathrm{z}$ drukiem i kolportażem nowego pisma. W skład redakcji weszli także Stefan Adamski i Stanisław Kowalski ${ }^{7}$ Kubasiewicz był w tym czasie bliskim współpracownikiem Bogdana Borusewicza. Jak wspominała Magdalena Czachor: „Marek Kubasiewicz był głównym kolporterem Borusewicza w 1982 roku. Współpracował ściśle z Piotrem Kapczyńskim i braćmi Błaszkiewiczami. Nikt już nie wspomina pisma «Gdańsk» - gazetki podziemia «Solidarności» w tamtym czasie - którym Marek głównie się zajmował. Drugą taka sprawą, w którą był bardzo zaangażowany był właśnie «Skorpion». Wydaje się logiczne, że dystrybuował wszystko tymi samymi kanałami"8.

Już na wstępie pojawił się problem z tytuŁem pisma. Stefan Adamski opowiadał się za nazwą „LONT" (Lotna Oficyna Niezależnej Twórczości), Joanna Duda-Gwiazda zaproponowała tytuł "Skorpion" (pisany na winiecie w formie "sKORpion"), a Marek Kubasiewicz zasugerował nazwę "KOR-nik”. Ostatecznie zwyciężył pomysł Joanny Dudy-Gwiazdy, która zdołała przekonać do niego swoich kolegów. Zawarty w tytule skrót KOR stanowił oczywisty ukłon w stronę Komitetu Samoobrony Społecznej „KOR”, z którego członkami łączyły założycieli nowego pisma więzy sympatii i osobiste znajomości ${ }^{9}$.

Z pismem współpracowali Andrzej Gwiazda, Wojciech Hrynkiewicz i Andrzej Mróz. W kolportaż zaangażowani byli: Urszula Adamus, Marek Balicki, Adam Burkiewicz, Ryszard Czajkowski, Andrzej Dorniak, Krzysztof Dowgiałło, Piotr Dyk, Wojciech Hrynkiewicz, Jacek Kozłowski, Karol Krementowski, Andrzej Leszczyński, Magdalena Modzelewska, Mariusz Muskat, Celina Mróz, Maryla Płońska, Alina Pienkowska, Bernadeta Stankiewicz, Zbigniew Stefański, Henryk Szabała, Joanna i Michał Wojciechowiczowie, Mariusz Wielebski, Krzysztof Wójcicki i Jan Zapolnik ${ }^{10}$.

Drukiem pisma zajmowali się też: Anna Brodzikowska, Magdalena i Marek Czachorowie, Krzysztof Jasik, Zbigniew Mielewczyk, Janusz Prendota,

4. Wszelkie pytania i uwagi związane z tekstem proszę kierować pod adres: piotr.brzezinski@ipn.gov.pl.

5. Regionalna Komisja Koordynacyjna powstała w Gdańsku w maju 1982 roku. W jej skład - oprócz wspomnianych: Borusewicza, Halla i Lisa - weszli też Stanisław Jarosz i Marian Świtek; więcej na ten temat zob. K. Knoch, Regionalna Komisja Koordynacyjna w Gdańsku w latach 1982-1989, [w:] Solidarność podziemna 1981-1989, red. A. Friszke, Warszawa 2006, s. 183-268.

6. Gwiazdozbiór w "Solidarności". Joanna i Andrzej Gwiazdowie w rozmowie z Remigiuszem Okraska, Łódź 2009 , s. 289.

7. Relacja Stefana Adamskiego z 30 stycznia 2020 (nagranie audio).

8. Relacja pisemna Magdaleny Czachor z 2 czerwca 2020 (w zbiorach autora).

9. Relacja Stefana Adamskiego z 30 stycznia 2020 (nagranie audio). Por. Od Redakcji, "Skorpion” 1982, nr 2, s. 1.

10. Relacja pisemna Stefana Adamskiego z 5 marca 2020 (w zbiorach autora). 
Wojciech Pytel i Daniel Trapkowski. Pismo drukowano na dość prymitywnym wałku ${ }^{11}$.

"Skorpion" opatrzony był podtytułem „Publicystyczno-literackie pismo podziemne" i adresowano go raczej do środowiska inteligenckiego. $\mathrm{Na}$ jego łamach ukazywały się artykuły informacyjne i publicystyczne, a także wiersze. Rubrykę informacyjną redagował Stanisław Kowalski, niektóre artykuły miały kilku autorów, a wiersze pisali: Stefan Adamski, Joanna Duda-Gwiazda, Wojciech Hrynkiewicz i Stanisław Esden-Tempski. Publikowano też przedruki z innych podziemnych czasopism. Na łamach "Skorpiona" prezentowano sylwetki aresztowanych działaczy opozycyjnych (np. Ewy Kubasiewicz) i sowieckich dysydentów (np. Jewgienija Jewtuszenki) ${ }^{12}$. W sumie ukazały się zaledwie trzy numery: pierwszy w październiku 1982 roku, drugi w listopadzie 1982, a trzeci - na przełomie 1982 i 1983. Pismo miało objętość dziesięciu stron i format A4. Nakład wynosił kilkaset egzemplarzy. Fundusze na działalność pozyskiwano $\mathrm{z}$ dobrowolnych wpłat i składek ${ }^{13}$.

Papier do druku udało się natomiast zgromadzić jeszcze przed wprowadzeniem stanu wojennego. Jak wspominała Magdalena Czachor: „Papier pochodził z drugiej piwnicy moich rodziców, która ocalała podczas kataklizmu w grudniu 1981 r. (Nie została przeszukana, a w niej było przechowywane ok 500 ryz papieru!). Jako że piwnica nie była zapełniona, mój ojciec pozwolił schować tam Antoniemu Mężydle ten papier chyba na potrzeby MKZ-u jeszcze przed stanem wojennym. Piwnica służyła po 13 grudnia 1981 r. do przechowywania wszystkiego - część rzeczy przechowywałam nawet w naszej «oficjalnej» piwnicy"14.
Papieru i sprzętu starczyło na wydanie trzech numerów. Jak wspominał Stefan Adamski: „Po ukazaniu się trzeciego numeru nastąpiła dłuższa przerwa - Marek Kubasiewicz żalił się, że zaczął mieć problemy z dojściem do sprzętu poligraficznego, pojawiły się też problemy z papierem. Mimo że usiłowała się o to zatroszczyć również Joanna swoimi kanałami (a oboje z Andrzejem cieszyli się przecież ogromnym autorytetem i popularnością), wyglądało to na jakąś ewidentną blokadę. Jeśli nawet zależało na tym szczególnie SB («Gwiazdozbiór» uznawany był za nieprzejednane, ba, wręcz «ekstremistyczne» skrzydło związku), to jednak trudności miały miejsce już na poziomie struktur konspiracyjnych. To, że nie trawią nas wierni wyznawcy Wałęsy, było poniekąd zrozumiałe, ale żeby owa blokada była aż tak szczelna?"15. Jak wspominała Joanna Gwiazda: "Od początku członkowie struktur związkowych podporządkowanych RKK mieli zakaz kontaktowania się ze mną. Tajni drukarze, do których dotarłam, bardzo przepraszali, ale Borusewicz kategorycznie zakazał im drukowania moich tekstów"16.

W dość nieoczekiwanym momencie tytuł pisma ponownie stał się problematyczny. Jak wspominał Stefan Adamski: „Nazwa ta okazała się pod jednym względem niezbyt fortunna, ze względu na osobliwą doprawdy koincydencję - otóż latem 1983 wszystkie ówczesne media podały informację, że specjalna grupa operacyjna M0 rozwiązała sprawę o kryptonimie «Skorpion». Pamiętam, że kilkoro moich ówczesnych znajomych relacjonowało mi, że w pierwszym momencie sądzili, iż chodzi o nasze skromne pisemko, tymczasem opatrzona tym kryptonimem sprawa miała charakter czysto kryminalny i dotyczyła seryjnego mordercy, niejakiego Pawła

11. Relacja pisemna Stefana Adamskiego z 5 marca 2020 (w zbiorach autora); relacja Magdaleny i Marka Czachorów z 23 stycznia 2020 (nagranie audio).

12. Relacja pisemna Stefana Adamskiego z 5 marca 2020 (w zbiorach autora).

13. Relacja Stefana Adamskiego z 30 stycznia 2020 (nagranie audio).

14. Relacja pisemna Magdaleny Czachor z 2 czerwca 2020 (w zbiorach autora).

15. Relacja pisemna Stefana Adamskiego z 5 marca 2020 (w zbiorach autora).

16. Gwiazdozbiór w "Solidarności", s. 292. 
Tuchlina. Przypadek, ale - przyznajmy - wywołujący niezbyt ciekawe skojarzenia, toteż pamiętam, że nawet deliberowaliśmy nad ewentualną zmianą nazwy $^{\prime 17}$. Faktycznie, wszelkie skojarzenia z głośnym w całym kraju mordercą kobiet z Pomorza mogłyby tylko zaszkodzić redakcji podziemnego pisma ${ }^{18}$.

Pomimo piętrzących się trudności przygotowano do druku czwarty numer "Skorpiona", który miał być wydrukowany na offsecie przez Piotra Kapczyńskiego. Jak wspominała Joanna Duda-Gwiazda: „Na offsecie można było nawet drukować rysunki. Hania Gwiazda, siostra Andrzeja, przygotowała znakomite satyryczne rysunki, a numer się rozrastał, ponieważ wciąż ktoś dopisywał jakiś ciekawy tekst"19. Numer ten nigdy jednak się nie ukazał, gdyż jego diapozytywy zostały skonfiskowane przez SB po aresztowaniu Stefana Adamskiego ${ }^{20}$.

Wkrótce potem Bogdan Borusewicz oskarżył Marka Kubasiewicza o współpracę z bezpieką ${ }^{21}$. Zdaniem Stefana Adamskiego oskarżenie to było nonsensem i przypominało sąd kapturowy ${ }^{22}$. Podobnego zdania było wiele innych osób. Jak wspominała Ewa Kubasiewicz-Houée: „Czyżby Bogdan Borusewicz przestał panować nad sytuacją i nie mógł zahamować tej sprawy, którą w ewiden- tny dla mnie sposób podchwyciła ubecja? Czyżby chodziło o wyeliminowanie mnie, czy może, co bardziej prawdopodobne, całego Gwiazdozbioru, który widział, że oskarżenie jest wyssane z palca? [...] Pragnienie, by opinia publiczna uwierzyła w agenturę «Dużego» [Marka Kubasiewicza], wydaje się ważne dla Bogdana, gdyż proponuje on Joannie współpracę pod warunkiem, że potwierdzi, iż Marek jest agentem. Joanna, oczywiście, nie przyjmuje tej propozycji"23. Joanna Duda-Gwiazda skomentowała to słowami: „Po oskarżeniu Marka Kubasiewicza o współpracę z SB Bogdan mógł już racjonalnie wytłumaczyć zakaz: «Joanna ufa agentowi, a jest podejrzliwa wobec sprawdzonych ludzi». Marek załamał się, gdy okazało się, że wszyscy ludzie podziemia, których uważał za przyjaciót, również Piotrek Kapczyński, uznali go za agenta. Uwierzył, że Borusewicz jest wszechmocny, i już nigdy nie dał się namówić do żadnej aktywności"24. W tej sytuacji Joanna Duda-Gwiazda zdecydowała się stworzyć zupełnie nowe pismo. Jak wspominała: „Tytuł narzucał się sam - byliśmy poza układem"25.

Oprócz niej w tworzenie "Poza Układem” zaangażowali się między innymi: Stefan Adamski,

17. Relacja pisemna Stefana Adamskiego z 5 marca 2020 (w zbiorach autora).

18. Więcej informacji na temat Pawła Tuchlina zob. R. Borowski, Tysiąc stron o seryjnym zabójcy Skorpionie, https://www.trojmiasto. pl/wiadomosci/Pierwsza-taka-ksiazka-o-sprawie-Pawla-Tuchlina-ps-Skorpion-n140639.html (dostęp: 29.05.2020).

19. Gwiazdozbiór w "Solidarności". Joanna i Andrzej Gwiazdowie w rozmowie z Remigiuszem Okraska, Łódź 2009 , s. 291.

20. Relacja pisemna Stefana Adamskiego z 5 marca 2020 (w zbiorach autora).

21. Nawet po latach Borusewicz określał Kubasiewicza mianem jednego z najbardziej niebezpiecznych agentów SB, z którymi przyszło mu się zetknąć (por. E. Szczesiak, Borusewicz. Jak runą mur. Rozmowy z liderem opozycji demokratycznej, legenda Sierpnia '80 oraz podziemia "Solidarności", pierwowzorem "Człowieka z żelaza", Warszawa 2005, s. 17). Nigdy nie przedstawił jednak dowodów potwierdzających agenturalność Kubasiewicza (por. E. Kubasiewicz-Houée, Bez prawa powrotu, Wrocław 2005, s. 140). Oskarżenie to okazało się zresztą zupełnie bezpodstawne, a w 2005 roku Kubasiewicz otrzymał od Instytutu Pamięci Narodowej status osoby pokrzywdzonej przez SB (Archiwum Zakładowe Instytutu Pamięci Narodowej w Gdańsku, AZ IPN Gd 73/57, Zaświadczenie nr 483/06, Gdańsk 30 V 2006 r., k. 20). Więcej informacji na ten temat zob. M. Czachor, List otwarty do Pana Profesora Andrzeja Friszke członka Kolegium IPN, Gdańsk, 19 IX 2005, https://old.sw.org.pl/relacje/friszke. html (dostęp: 28.05.2020); idem, Marek Kubasiewicz otrzymał z IPN status pokrzywdzonego, [b.m.d.] https://jozefdarski. pl/612-marek-kubasiewicz-otrzymal-z-ipn-status-pokrzywdzonego (dostęp: 1.06.2020).

22. Relacja Stefana Adamskiego z 30 stycznia 2020 (nagranie audio).

23. E. Kubasiewicz-Houée, Bez prawa powrotu, s. 141-142.

24. Gwiazdozbiór w "Solidarności", s. 292.

25. Ibidem, s. 292. 
Stanisław Kowalski, Karol Krementowski, Ewa Kubasiewicz i Wiesława Kwiatkowska ${ }^{26}$. Chcąc dodatkowo zakonspirować nowe pismo, Joanna Duda-Gwiazda starała się ukryć wszelkie swoje związki z redakcją. Jak wspominała: „Metody kamuflażu okazały się skuteczne, chociaż były bardzo proste. Na przykład nawet rozdając «Poza Układem» zastanawiałam się, kto wydaje takie dziwaczne pisemko i bardzo często je krytykowałam. Borusewicz robił mi opinię osoby nieporadnej, która tylko gada, a nic nie robi, co bardzo mi pomagało. Podziemie naprawdę nie wiedziało, skąd wzięło się w regionie to kukułcze jajo"27. Wydaje się, że pismo było też zagadką dla bezpieki, gdyż jej redakcja przez cały czas swojego funkcjonowania zdołała uniknąć aresztowania.

Pierwszy numer „Poza Układem” ukazał się w styczniu 1984 roku. Początkowo drukiem zajmowali się pracownicy gdańskiego Unimoru: Zdzisław Szydłowski, Maria Litwinowicz, Alicja Kwiatkowska, Elżbieta Knot i Renata Obolewicz. Matryce dostarczyła Joanna Duda-Gwiazda, a druk odbywał się na powielaczu w mieszkaniu Renaty Obolewicz na gdańskim Przymorzu. Niekiedy drukowano też na terenie położonego przy ulicy Wileńskiej sadu owocowego należącego do Karola i Teresy Krementowskich ${ }^{28}$. Jednym z ważniejszych punktów kolportażu pisma było zaś mieszczące się przy ulicy Białej mieszkanie Stanisława i Urszuli Kowalskich, czyli rodziców Magdaleny Czachor, a teściów Marka Czachora ${ }^{29}$.

Na tej samej ulicy znajdowało się mieszkanie Jerzego i Stefanii Orchowskich, którzy też pomagali w wydawaniu pisma. Jak wspominała Ewa Kubasiewicz-Houée: „Pisałam tam na maszynie «Poza Układem» i później «Biuletyn SWT». [...] Z ich mieszkania były odbierane przez Karola Krementowskiego materiały do druku «Poza Układem» i pewnie też «Biuletynu SWT». W ich mieszkaniu spotykałam się z Francuzami, z Josephem Courné i Remi Marchand, którzy przywozili z Bretanii pomoc dla «Poza Układem» i «Biuletynu SWT». [...] Ich mieszkanie było bardzo ważnym miejscem konspiracyjnym" ${ }^{\prime 30}$.

Nakład pisma wynosił kilkaset egzemplarzy ${ }^{31}$. Objętość poszczególnych numerów wahała się od ośmiu do czternastu stron formatu A4. Począwszy od numeru czwartego, który ukazał się w grudniu 1984 roku, szata graficzna znacząco się poprawiła, a pismo zaczęto drukować techniką sitodruku ${ }^{32}$. Pierwsze cztery numery „Poza Układem” nosiły adnotację informującą, że działalność pisma finansowana jest $\mathrm{z}$ własnych środków. Począwszy od numeru piątego, na ostatniej stronie pojawiła się adnotacja, że jest ono drukowane nakładem Wydawnictwa "Solidarność Walcząca Trójmiasto". Od tego momentu pismo drukowane było przez Andrzeja Kołodzieja, Ewę Kalisz, Jerzego Kanikułę, Jacka Parzycha oraz Małgorzatę i Romana Zwiercanów, a w późniejszym okresie także przez Piotra Komorowskiego, Jędrzeja Terlikowskiego i Daniela Trapkowskiego ${ }^{33}$. Ogółem w latach 1984-1986 ukazało się dziesięć numerów "Poza Układem”, a ostatni z nich wydrukowano wiosną 1986 roku. Następnie pismo przestało się ukazywać na blisko

26. Dwie ostatnie zaangażowały się w działalność wydawniczą dopiero po wyjściu na wolność. Ewa Kubasiewicz przebywała w więzieniu od grudnia 1981 do maja 1983 roku, a Wiesława Kwiatkowska od grudnia 1981 do marca 1983.

27. Gwiazdozbiór w "Solidarności", s. 289.

28. Relacja Karola Krementowskiego z 29 listopada 2019 (nagranie audio).

29. Relacja Magdaleny i Marka Czachorów z 23 stycznia 2020 (nagranie audio).

30. Relacja pisemna Ewy Kubasiewicz-Houée z 3 czerwca 2020 (w zbiorach autora). Za udostępnienie relacji dziękuję Markowi Czachorowi.

31. Relacja Karola Krementowskiego z 29 listopada 2019 (nagranie audio).

32. Relacja Magdaleny i Marka Czachorów z 23 stycznia 2020 (nagranie audio).

33. A. Kołodziej, R. Zwiercan, 0 godność i wolność. Po prostu... Solidarność Walcząca w Trójmieście w latach 1982-1990, Kościerzyna 2010, s. 106. Niektóre źródła podają informację, że SW drukowała "Poza Układem” dopiero od numeru szóstego (D. Cecuda, Leksykon Opozycji politycznej 1976-1989, Warszawa 1989, s. 181). 
trzy lata. Joanna i Andrzej Gwiazdowie wspominali, że do zaniechania druku skłonił ich brak reakcji polskiej inteligencji na katastrofę w elektrowni atomowej w Czarnobylu wiosną 1986 roku $^{34}$. Podobną opinię wyraził Stefan Adamski ${ }^{35}$. Niewykluczone, że do zawieszenia publikacji mogły też przyczynić się problemy ze zdobyciem środków pieniężnych i materiałów poligraficznych.

\section{Antyrządowe i antywałęsowskie ostrze}

Karol Krementowski scharakteryzował linię programową "Poza Układem” następująco: „Pismo było antyrządowe i antywałęsowskie jednocześnie" ${ }^{\prime \prime 36}$. Mówiąc zaś językiem władz PRL, reprezentowało ono tak zwaną ekstremę Solidarności. W jego tworzenie zaangażowani byli ludzie reprezentujący różne środowiska ideowe. Jak wspominała Joanna Duda-Gwiazda: „Poza układem znalazły się osoby o bardzo różnych poglądach - związkowcy, narodowcy, republikanie, socjaliści, konserwatyści, katolicy, anarchiści - które zachowały niezależność, nie dały się w układ wmontować" ${ }^{\prime \prime 7}$. Pismo adresowane było do inteligencji, a tematyka podejmowana na jego łamach koncentrowała się na kwestiach społecznych i politycznych. Joanna i Andrzej Gwiazdowie podkreślają, że miało ono "długi termin ważności", co oznaczało, że drukowane w nim teksty długo zachowywały aktualnośćs ${ }^{38}$. Podobnie jak w przypadku "Skorpiona”, redakcja pisma stawiała bardziej na publicystykę niż na bieżącą informację. Teksty zwykle publikowano anonimowo lub pod pseudonimami. Pismo ukazywało się nieregularnie, czasem co miesiąc, a czasem co kilka miesięcy ${ }^{39}$.
Już w pierwszym numerze zamieszczono artykuł Złodzieje słów ukradli nam porozumienie, w którym znalazło się wiele uwag na temat komunizmu. Jak można w nim przeczytać: „Komuniści wprowadzając swój ustrój w Polsce przejęli wszystkie hasła polskiej lewicy, sprawiali nawet wrażenie, że je realizują. Mieliśmy więc demokrację, socjalizm, sprawiedliwość społeczną, tolerancję, a także reformę rolną, powszechną oświatę i ubezpieczenia, a nawet równouprawnienie kobiet. Mieliśmy tych słów i pięknych haseł w nadmiarze, a opisywana przez nie rzeczywistość coraz bardziej przypominała koszmarny sen - bezwzględny wyzysk, terror, bezprawie, krzywdę ludzką" ${ }^{40}$. Autor tekstu nie poprzestał jednak na tej konstatacji i zauważył, że także Solidarność szybko zaczęła używać drętwej nowomowy: „Pierwsze komunikaty, oświadczenia i uchwały MKS-u i MKZ-u były jeszcze krótkie i jednoznaczne, gdyż redagowane przez ludzi przyzwyczajonych w działalności opozycyjnej do odpowiedzialności za słowo. Później, po powstaniu masowej organizacji, język Solidarności zagmatwał się i upodobnił do gazetowej mowy-trawy"41. Publikacja tych uwag w podziemnym piśmie opozycyjnym pozornie mogła się wydawać szarganiem wizerunku niszczonej przez komunistów Solidarności, w rzeczywistości dowodziła jednak odwagi jego redakcji w podejmowaniu trudnych tematów.

Stałym elementem publicystyki „Poza Układem" były informacje o represjach wobec działaczy Solidarności i losie osób więzionych za przekonania - w partyjnej i esbeckiej nowomowie nazywanych wówczas „więźniami niekryminalnymi". W pierwszym numerze opublikowano na przykład tekst informu-

34. Gwiazdozbiór w "Solidarności", s. 291-292.

35. Relacja Stefana Adamskiego z 30 stycznia 2020 (nagranie audio).

36. Relacja Karola Krementowskiego z 29 listopada 2019 (nagranie audio).

37. Gwiazdozbiór w "Solidarności", s. 293.

38. Relacja Andrzeja i Joanny Gwiazdów z 11 grudnia 2019 (nagranie audio).

39. Półroczna przerwa w wydawaniu pisma pomiędzy grudniem 1984 a majem 1985 roku wynikała z aresztowania Stanisława Kowalskiego i czasowej dezorganizacji kontaktów redakcji pisma z trójmiejską strukturą Solidarności Walczącej (Relacja pisemna Marka Czachora z 2 czerwca 2020 - w zbiorach autora).

40. J. Kowalski, Złodzieje słów ukradli nam porozumienie, "Poza Układem” 1984, nr 1, s. 1. 
jący o aresztowaniu Anny Walentynowicz, a także głośny swego czasu list Adama Michnika do generała Czesława Kiszczaka.

Drugi numer rozpoczynał się wywiadem przeprowadzonym z przebywającym w areszcie Andrzejem Gwiazdą. Jak łatwo się domyśleć, został on przemycony do redakcji w formie grypsu. W tym samym wydaniu zamieszczono informację o śmiertelnym pobiciu przez "nieznanych sprawców" młodego gdańskiego muzyka Jacka Stefańskiego ${ }^{42}$, a także artykuł o więźniach politycznych. Autor tego ostatniego tekstu zwrócił uwagę na ambiwalentny stosunek polskiego społeczeństwa do osób więzionych za przekonania. Jak stwierdził: "Jeśli w więzieniu nie dzieje się nic nadzwyczajnego, nikt nie umiera, nikogo nie biją i nie głodzą, nikt nie prowadzi dramatycznej głodówki, sumienie wielu ludzi pozostaje spokojne, a opinia publiczna przestaje interesować się tym problemem. Walkę o uwolnienie więźniów odkładamy na czas nieokreślony, do jakiegoś korzystniejszego momentu. Brak nam wrażliwości, odwagi i mądrości politycznej, aby o uwolnienie więźniów politycznych walczyć konsekwentnie i wytrwale" ${ }^{\prime \prime 3}$. Wspomniany tekst był kolejnym dowodem na to, że redakcja „Poza Układem" nie wahała się dotykać drażliwych kwestii społecznych, tym bardziej że podziemna Solidarność faktycznie nie potrafiła zorganizować skutecznej akcji w obronie więźniów politycznych ${ }^{44}$.

Trzeci numer rozpoczynał się wywiadem przeprowadzonym z ukrywającym się przed bezpieką liderem Solidarności Walczącej Kornelem Morawieckim. Opisywał on w nim okoliczności powstania kierowanej przez siebie organizacji oraz cele jej działalności ${ }^{45}$. Warto zauważyć, że w latach osiemdziesiątych Andrzej i Joanna Gwiazdowie blisko współpracowali z Solidarnością Walczącą, a ich pisma były drukowane przez podziemną drukarnię SW. Mimo to po latach Andrzej Gwiazda stwierdzit, że w ogólnym rozrachunku powstanie Solidarności Walczącej odegrało negatywną rolę, gdyż osłabiło podziemną Solidarność, odciągając od niej najbardziej ideowych i pryncypialnych działaczy ${ }^{46}$.

W otwierającym numer czwarty tekście $\mathrm{Na}$ sza geopolityka Andrzej Gwiazda dokonał analizy sytuacji społeczno-politycznej, stwierdzając, że prezentowany przez władze PRL oficjalny spokój jest tylko przykrywką dla ich narastającego niepokoju o własną przyszłość: „Wydawać by się mogło, że ekipie, która już nie oczekuje poparcia, zadowalając się jedynie biernością społeczeństwa, obecna sytuacja może odpowiadać. Generałowie i sekretarze mają władzę i chociaż się to wszystko rozsypuje, społeczeństwo nie jest w stanie im tej władzy odebrać. Oprócz władzy mają też buty, szynkę, masło, mundury i ciuchy dla żon. Jednak stan istniejący nie zapewnia stabilności władzy, poczucia tej pewności" ${ }^{\prime \prime 7}$. Kolejne lata w pełni dowiodły trafności tej diagnozy. W tym samym wydaniu znalazł się artykuł zatytułowany Richard Nixon o odprężeniu realnym, w którym można było znaleźć ciekawe

41. Ibidem, s. 2.

42. Jacek Stefański zmarł 9 sierpnia 1983 roku, zob. J. Chrząstek, Jak powstał zespół "Bez Jacka", http://bezjacka.art.pl/strona/ historiabj/ (dostęp: 27.05.2020).

43. Ludzie po obu stronach krat, "Poza Układem” 1984, nr 2, s. 7-8.

44. Jak zauważyli Jerzy Holzer i Krzysztof Leski: „Działania podejmowane na zewnątrz więzień w obronie aresztowanych i skazanych nigdy nie przebiły barier braku pomysłu na skuteczną akcję i narastającego zmęczenia społeczeństwa, zajętego codzienną walką o byt" (J. Holzer, K. Leski, Solidarność w podziemiu, Łódź 1990, s. 110).

45. Głos z podziemia. PU rozmawia z Kornelem Morawieckim, "Poza Układem” 1984, nr 3, s. 1-3.

46. Relacja Andrzeja Gwiazdy z 11 grudnia 2019 (nagranie audio). Z poglądem tym nie zgadzają się Magdalena i Marek Czachorowie, którzy stwierdzają, że podział działaczy podziemia na członków S i SW jest sztuczny, a w SW działało wielu ludzi, którzy formalnie nigdy do niej nie należeli i działalności w SW nie traktowali jako konkurencji dla członkostwa w S (Relacja Magdaleny i Marka Czachorów z 23 stycznia 2020 - nagranie audio).

47. A. Gwiazda, Nasza geopolityka, "Poza Układem” 1984, nr 4, s. 1. 
porównanie polityki zagranicznej prowadzonej przez USA i ZSRS ${ }^{48}$.

Piąty numer ukazał się w grudniu 1984 roku i nieprzypadkowo pod jego winietą znalazł się napis: „Uczcijmy pamięć ofiar Grudnia 1970 i 1981! Kontynuujmy tradycje Wolnych Związków Zawodowych Wybrzeża i NSZZ «Solidarność»!". Numer ten rozpoczynał się artykułem Andrzeja Gwiazdy "Solidarność" - związek zawodowy, czy antykomunistyczny ruch niepodległościowy. Czytamy w nim: „Jeszcze w 1981 r. uważałem «Solidarność» za typowy związek zawodowy. Uchwałę KZD przekształcającą «S» w «ruch społeczny» traktowałem jako przejaw uogólnionego sposobu myślenia delegatów. Ta decyzja nic nie dała, oprócz formalnej i zgodnej z prawem delegalizacji. Obecnie muszę zrewidować ten pogląd. «S» jest tym, za co uważa ją większość członków. A większość ludzi uznaje «S» za bliżej nieokreślony ruch, który tworzą wszystkie ugrupowania niezgadzające się z polityką PZPR"49. Tym samym wiceprzewodniczący Solidarności przyznał otwarcie, że od jesieni 1981 roku związek oficjalnie przekształcił się w zorganizowaną opozycję polityczną, co po 13 grudnia 1981 stało się dla komunistów pretekstem do jego delegalizacji ${ }^{50}$. W gruncie rzeczy w oczach władz PRL Solidarność od samego początku była istotną siłą polityczną. Podobnie zresztą oceniali ją niektórzy niezależni komentatorzy ${ }^{51}$.

W opublikowanym w tym samym numerze artykule Lewica i prawica można znaleźć wiele uwag na temat Kościoła katolickiego, który zdaniem redakcji „Poza Układem” po 13 grudnia 1981 roku znacznie zwiększył swój wpływ na Solidarność: „Początkowo Kościół organizował tylko działalność charytatywną dla uwięzionych i represjonowanych. Już wtedy przy parafiach i szybko powołanych komisjach charytatywnych skupiła się znaczna część działaczy związkowych, którzy chcieli organizować pomoc dla kolegów. Z biegiem czasu przy Kościele zaczął organizować się niezależny ruch kulturalny i oświatowy. Msze w intencji uwięzionych i 0jczyzny gromadzą rzesze ludzi pragnących zamanifestować swoje uczucia i poglądy. W kościele i na uroczystościach religijnych może przemówić Lech Wałęsa. W kościele można spotkać znanych działaczy. W kościele gromadzą się ludzie, którzy potem mogą pomaszerować pod pomnik lub na trasę pochodu 1-szo majowego. Działalność pod osłoną Kościoła jest znacznie bezpieczniejsza i wydaje się bardziej skuteczna. Ciężar działalności przesunął się z zakładów pracy do Kościoła"52. Doceniając znaczenie Kościoła w podtrzymywaniu oporu społecznego przeciw komunizmowi, redakcja zwracała też uwagę na nasilającą się klerykalizację podziemnej Solidarności: „Obecnie aktywność działaczy związkowych oceniana jest na podstawie uczestnictwa w mszach św. za 0jczyznę i pielgrzymkach. Ich pozycja - odległością od ołtarza"53. Po latach Andrzej Gwiazda stwierdził, że sytuacja ta doprowadziła wręcz do zbieżności interesów hierarchii kościelnej oraz części elit komunistycznych i solidarnościowych, których wspólnym celem stała

48. Richard Nixon o odprężeniu realnym, "Poza Układem” 1984, nr 4, s. 2.

49. A. Gwiazda, "Solidarność" - związek zawodowy, czy antykomunistyczny ruch niepodległościowy, "Poza Układem” 1984, nr 5, s. 1.

50. Por. L. Mażewski, Ustrojowopolityczny taran. Polityka NSZZ "Solidarność" a przemiany ustrojowe w PRL w latach 1980-1982, Warszawa-Radzymin 2017, s. 231-232.

51. Jak pisał latem 1981 roku Stefan Kisielewski: „Mówić, że powstanie spontanicznych związków pracowniczych w kraju, gdzie przez 35 lat związki takie były fikcją i przybudówką władzy, nie jest zjawiskiem politycznym, to zaiste duża obłuda. Usprawiedliwiają ją zapewne względy taktyczne, ale słabe to usprawiedliwienie, bo w apolityczność nowej, przez «Solidarność» wytworzonej sytuacji, mało kto dzisiaj w Polsce wierzy. Od polityki nikt już teraz nie ucieknie, zamiast więc wyrzekać się jej gorliwie a mało wiarygodnie, może lepiej by było usunąć nieporozumienia i zmierzyć się z nią otwarcie?" (S. Kisielewski, Czego oczekuję od "Solidarności", "Tygodnik Solidarność" 1981, nr 13, s. 5).

52. Lewica i prawica, "Poza Układem” 1984, nr 5, s. 6.

53. Ibidem. 
się eliminacja z władz związku osób „reprezentujących opcję związkową, WZZ-owską, demokratyczną" ${ }^{54}$.

Szósty numer skupiał się na sprawach stricte politycznych i można było w nim znaleźć następującą deklarację: „Jeśli mamy być normalnym społeczeństwem zdolnym do zorganizowania dobrze funkcjonującego państwa, nie możemy bać się polityki. Polityka jest dla wszystkich, a ambicje polityczne nie różnią się niczym od innych - zawodowych, sportowych czy artystycznych" ${ }^{25}$. Jak zauważył autor tego tekstu: „Przywódców «Solidarności» propaganda próbowała podzielić na tych, co robią «czyste związki» i politykierów. [...] Do politykierów zaliczano tych, którzy mieli przemyślaną koncepcję działania «S» i dobre rozeznanie w problemach ludzi w zakładach pracy. Byli bardziej niebezpieczni dla władzy, więc straszono członków «S» ich "politycznością)" ${ }^{\prime \prime}$. W ten sposób dawano odpór rządowej propagandzie, która często zarzucała związkowi nadmierne upolitycznienie.

We wspomnianym numerze można też znaleźć interesujące refleksje na temat roli przywódcy politycznego: „Przywódca, który idzie kilka kroków przed ludźmi może zaprowadzić ich do odległego nawet celu. Przywódca, który idzie kilka kilometrów przed ludźmi jest samotnym podróżnikiem, a tłum pójdzie za kimś innym. Gdyby jako cel strajku sierpniowego postanowić niepodległość, czyli tłumacząc to na język praktyczny zażądać wolnych wyborów, zamiast [Mieczysława] Jagielskiego przyjechałyby czołgi. Ale nie byłby to jedyny «kłopot». Wtedy ludzie nie zaakceptowaliby takiego żądania. Wcale nie dlatego, że nie rozumieli co to są wolne wybory lub nie zgadzali się z tym postulatem. Propagowanie wolnych wyborów byłoby chyba nawet łatwiejsze niż wyjaśnianie idei Wolnych Związków Zawodowych. Ludzie nie strajko- waliby o wolne wybory, ponieważ czuli nierealność tego postulatu, a ponadto idea WZZ-tów była bliższa ich dotychczasowym doświadczeniom" ${ }^{57}$. To właśnie dlatego z pierwotnej listy sformułowanych w sierpniu 1980 roku postulatów skreślono nierealny do osiągnięcia postulat wolnych wyborów do Sejmu PRL ${ }^{58}$.

W otwierającym numer siódmy artykule Krajobraz po bitwie można zaleźć krytyczną ocenę działalności Lecha Wałęsy i jego stosunku do generała Wojciecha Jaruzelskiego. Zdaniem autora tego tekstu Wałęsa "Wierzył, że generał chce dobrze, ale nie wie jak lud cierpi, jak gnębią go nieudolni i chciwi urzędnicy, dyrektorzy, sekretarze i boi się zmian, bo nie ufa swoim poddanym. Wyższą polityką nie zaprzątał sobie głowy. Trochę mimo woli, trochę świadomie, ratował generała w każdym momencie dogodnego ataku. Tak było w marcu 1981 r., w listopadzie 1982 r. po delegalizacji «Solidarności», a przed aresztowaniem jej przywódców, w listopadzie 1984 r. po zamordowaniu ks. Jerzego, w lutym 1985 r. przed strajkiem. Potem trochę tracił popularność, ale szybko odrabiał straty jakimś gestem, oświadczeniem, wywiadem. Zatrzymywał się zawsze w bezpiecznej odległości od zdrady, bo zawsze chciał dobrze, bo naprawdę nie zdradził siebie, swojej natury, swoich poglądów, których zresztą nigdy nie ukrywał. Lud wyniósł go ze stoczni po strajku na rękach i gotów nosić go na rękach nadal, jeśli tylko zostanie dopuszczony do gry. W czasie wojny polsko-jaruzelskiej jeden Wałęsa, z pomocą nagrody Nobla ${ }^{59}$ na zawsze utrwalił swoją pozycję. Nie poniósł również żadnych strat fizycznych czy materialnych. W izolacji spędził luksusowy urlop $z$ rodziną, był dobrze traktowany, zachował zdrowie, pracę, mieszkanie, samochody"60.

54. Gwiazdozbiór w "Solidarności”, s. 208.

55. Polityka - owoc zakazany, "Poza Układem” 1985, nr 6, s. 2.

56. Ibidem, s. 1.

57. Polityka - co to jest?, "Poza Układem” 1985, nr 6, s. 3.

58. Zob. A. Friszke, Rewolucja Solidarności 1980-1981, Kraków 2014, s. 34; L. Mażewski, Ustrojowopolityczny taran, s. 45.

59. Lech Wałęsa otrzymał Pokojową Nagrodę Nobla w październiku 1983 roku.

60. Krajobraz po bitwie, "Poza Układem” 1984, nr 7, s. 1-2. Więcej informacji na temat przebiegu internowania przewodniczącego "Solidarności" zob. Kryptonim 333. Internowanie Lecha Wałęsy w raportach funkcjonariuszy Biura Ochrony Rządu, wstęp i oprac. T. Kozłowski, G. Majchrzak, Chorzów 2012. 
W artykule poddano też krytyce działalność Kościoła katolickiego i Tymczasowej Komisji Koordynacyjnej ${ }^{61}$, zarzucając im moralne rozbrajanie solidarnościowego podziemia. 0 ile jednak Kościół - zdaniem autora tego tekstu - potrafił umiejętnie odnaleźć się w tej sytuacji, a nawet uzyskiwać od władz pewne koncesje, o tyle działalność TKK wydawała mu się kompletnie niezrozumiała: „Dlaczego ukrywający się działacze «Solidarności», którzy nie mogli liczyć na żadne koncesje ze strony władzy, hamowali walkę jest zagadką, której w kategoriach politycznych rozwiązać nie można. Zadaniem dla psychologów jest opisanie przedziwnego splotu niekompetencji, pewności siebie, iluzji co do możliwości rozmów i porozumienia, lęku przed utratą autorytetu i równocześnie lęku przed zemstą komunistów. Nawet jeśli członkowie TKK nie wierzyli w zwycięstwo, to i tak jedynie konsekwentny, zacięty opór umacniał ich pozycję, dawał szanse obrony po aresztowaniu lub korzystniejsze warunki przy kapitulacji"62. Joanna i Andrzej Gwiazdowie do dziś podtrzymują ten pogląd, twierdząc, że „Tymczasowa Komisja Koordynacyjna, świadomie lub nie, częściowo wpisała się w scenariusz władzy"63. Mimo wszystko trudno oprzeć się wrażeniu, że zarzucana przez redakcję „Poza Układem” bierność TKK i RKK wobec represyjnych działań władz komunistycznych wynikała nie tyle $\mathrm{z}$ bojaźliwości ich kierownictwa, co z ogólnej słabości solidarnościowego podziemia ${ }^{64}$. Za pierwszy symptom tej słabości można było zresztą uznać niewielki opór społeczny wobec wprowadzenia stanu wojennego $0^{65}$.

Polemiczny charakter miała też zamieszczona w siódmym numerze recenzja wydanej na emigracji i cieszącej się dużą popularnością Konspiry ${ }^{66}$. Autor recenzji stwierdził, że książka ta, choć dobrze napisana, "nie oddaje prawdy o sytuacji ukrywającego się działacza. Za dużo w niej publicystyki, anegdoty, bohaterstwa. «Konspira» nie jest historią TKK, a tym bardziej podziemia. Nie daje pojęcia o rozwoju sytuacji politycznej, ani o taktyce komuny"67.

Ósmy numer pisma był nietypowy, gdyż w całości składały się na niego satyryczne wiersze anonimowego autorstwa. Po latach do ich napisania przyznała się Joanna Gwiazda ${ }^{68}$.

Numer dziewiąty rozpoczynał się wywiadem z Andrzejem Gwiazdą. Zastanawiając się nad możliwościami rozwoju dalszej sytuacji w kraju, stwierdził on, że solidarnościowe podziemie ogranicza się do pustych deklaracji i nie podejmuje konkretnych działań, które mogłyby przynieść zauważalne rezultaty. „Aby zacząć zwyciężać - konkludował Gwiazda - trzeba zejść z obłoków. Nie ma metod bezwzględnie dobrych. Dobre są te metody, do których ludzi da się przekonać. Właściwe są te cele, o które ludzie już dziś są gotowi podjąć walkę, a nie te, które

61. TKK powstała w kwietniu 1982 roku w wyniku porozumienia zawartego przez ukrywających się w podziemiu przedstawicieli regionalnych struktur "Solidarności" z Dolnego Śląska, Gdańska, Małopolski i Mazowsza. Pod jej dokumentem założycielskim podpisali się: Zbigniew Bujak, Władysław Frasyniuk, Władysław Hardek i Bogdan Lis. Więcej informacji na ten temat zob. A. Friszke, Tymczasowa Komisja Koordynacyjna NSZZ "Solidarność" (1982-1987), [w:] Solidarność podziemna 1981-1989, s. 17-182.

62. Krajobraz po bitwie, "Poza Układem” 1984, nr 7, s. 2.

63. Gwiazdozbiór w "Solidarności”, s. 294.

64. Jak zauważył Konrad Knoch: „Rok 1984 pokazał, że to, co miał do zaproponowania ruch podziemny, często okazywało się nieskuteczne, opór społeczny malał, społeczeństwo było zmęczone dotychczasowymi formami protestu, a może protestowaniem w ogóle" (K. Knoch, Regionalna Komisja Koordynacyjna w Gdańsku w latach 1982-1989, s. 266).

65. W połowie lat osiemdziesiątych Andrzej Gwiazda skomentował to następująco: „Mieliśmy masę bohaterskich postaw, ale w końcu cały kraj nie stanął. Ludzie nie wiedzieli, co robić. Jak kierownictwo zamknęli, reszta poszła do roboty. Trudno. Winę ponoszą nie ci ludzie, tylko kierownictwo, które w takim stanie dało się rozbić, że ludzie nie wiedzieli co robić" (J. Jankowska, Portrety niedokończone. Rozmowy z twórcami "Solidarności" 1980-1981, wstęp i oprac. A. Friszke, Warszawa 2003, s. 128).

66. Zob. M. Łopiński, M. Moskit, M. Wilk, Konspira. Rzecz o podziemnej Solidarności, Paris 1984.

67. "Konspira” czyli siedmiu wspaniałych, "Poza Układem” 1984, nr 7, s. 4-5.

68. Relacja Joanny i Andrzeja Gwiazdów z 11 grudnia 2019 (nagranie audio). 
lokują są w sferze najgorętszych nawet pragnień. Jeśli ludzie są sterroryzowani i zastraszeni, trzeba propagować cele i metody, które ich nie narażą na większe represje, a dają szanse zwycięstwa. Mogą i powinny to być zwycięstwa małe. $Z$ czasem i cele, i zwycięstwa, będą rosły coraz szybciej. Wymaga to jednak żmudnej, trudnej i długiej pracy, za którą w przyszłości nie będą przypinać orderów. Dlatego większą popularnością cieszą się wspaniałe hasła, mimo że nie poruszają nas naprzód"69. Była to niezwykle celna, lecz gorzka refleksja.

W tym samym wywiadzie Andrzej Gwiazda zwrócił uwagę na postępujące słabnięcie Solidarności, które w jego przekonaniu wynikało z podświadomej nadziei niektórych działaczy na to, że represje stanu wojennego zostaną cofnięte w wyniku interwencji Zachodu lub Stolicy Apostolskiej: „Słusznie, czy niesłusznie, TKK nie podjęła ryzyka walki bezpośredniej. Wezwanie do strajku generalnego w obronie «Solidarności» nie padło, a czas - uciekał. Zbyt długo członkowie «Solidarności» łudzili się, że odzyskają swoje prawa w wyniku dyplomatycznych zabiegów Episkopatu i Przewodniczącego, wspartych przez międzynarodowe autorytety 0jca Świętego i Ronalda Reagana. Duży procent działaczy związkowych wyemigrował. Inni skupili się wokół parafii i Komisji Charytatywnych znajdując tam szersze możliwości. Choć pożyteczne, działania te nie miały charakteru związkowego. TKZ-ty ${ }^{70}$ związane wymogami konspiracji, ścigane przez WUSW i administrację zaprzestały, a ściślej mówiąc, z wyjątkiem nielicznych, nigdy nie podjęły organizowania załóg do obrony przed wyzyskiem. Nawet te najlepsze ograniczają się do działań opiekuńczych (składki i zapomogi), symbolicznych (pocztówki świąteczne) i kolportażu prasy podziemnej, którą trudno nazwać związkową"71. Uważna lektura tego wywiadu uzmysławia nam, że w połowie lat osiemdziesiątych właściwie nic nie wskazywało na to, że solidarnościowe podziemie wyjdzie zwycięsko ze starcia z komunistyczną dyktaturą ${ }^{72}$.

Andrzej Gwiazda zauważył też, że pod płaszczykiem stanu wojennego i politycznych represji wobec opozycji władze PRL przeprowadziły wiele niekorzystnych dla pracobiorców zmian prawnych: "Tymczasem pracodawca drastycznie ograniczył wynagrodzenie, dopłaty za nadgodziny, zasiłki chorobowe $\mathrm{i}$ inne świadczenia. Ograniczono prawa pracownika i poszerzono prawa pracodawcy przy rozwiązywaniu umowy o pracę i zmianę miejsca pracy. Zmieniono kodeks pracy na niekorzyść pracownika. Pogorszyły się warunki BHP. Z zakładów pracy zwolniono lub aresztowano ludzi odważnych, cieszących się autorytetem i zaufaniem kolegów"73. Troska o zwykłych pracowników była charakterystyczna dla środowiska "Gwiazdozbioru" już od czasów działalności w WZZ.

Jako remedium na wyzysk zwykłych ludzi, a także jako formę nacisku na władze Andrzej Gwiazda postulował organizację strajków: „Monopolistyczny pracodawca ciągle może sobie pozwolić na stłumienie strajku w jednym zakładzie pracy, bez względu na straty ekonomiczne, ale też nigdzie strajk nie ma takiego znaczenia politycznego jak u nas, niezależnie od tego jakie są żądania strajkowe. [...] W gospodarce nieefektywnej, pozbawionej rezerw, nastawionej na maksymalny eksport i maksymalny wyzysk siły roboczej, nawet niewielkie

69. Wywiad z Andrzejem Gwiazdą dla "Kontaktów" (pismo nauczycieli), "Poza Układem” 1986, nr 9, s. 2.

70. Tajne Komisje Zakładowe - podziemne struktury "Solidarności" tworzone po wprowadzeniu stanu wojennego na terenie zakładów pracy.

71. Wywiad z Andrzejem Gwiazdą dla "Kontaktów" (pismo nauczycieli), s. 4.

72. Więcej informacji na temat funkcjonowania podziemnej „Solidarności” zob. m.in.: Droga do niepodległości. Solidarność 1980-2005, red. A. Borowski, Warszawa 2005; B. Drwęski, Zagrabiona historia Solidarności. Został tylko mit, tłum. J. Dobrzański, Warszawa 2020; J. Holzer, K. Leski, Solidarność w podziemiu, Łódź 1990; A. Modzelewska, Struktury organizacyjne NSZZ "Solidarność" w latach 1980-1989, Kraków 2020; Solidarność podziemna 1981-1989, red. A. Friszke, Warszawa 2006; R. Terlecki, "Solidarność". Dekada nadziei 1980-1989, Warszawa 2010.

73. Wywiad z Andrzejem Gwiazda dla "Kontaktów” (pismo nauczycieli), s. 4. 
straty mogą być odczuwalne przez pracodawcę. Jeśli pracodawcą jest państwo, strajk stanowi zagrożenie jego władzy gospodarczej, politycznej i ideologicznej. Również dla niższych szczebli aparatu władzy strajk jest niebezpieczny"74. Przebieg wydarzeń następujących bezpośrednio po strajkach z 1988 roku zdawał się w pełni potwierdzać tę argumentację, przy czym należy zaznaczyć, że protesty te były jedynie słabym echem strajków z 1980 roku.

Dziesiąty numer rozpoczynał się artykułem Geopolityka a niepodległość, w którym podjęto próbę analizy międzynarodowego położenia Polski. W tekście zatytułowanym Jacy jesteśmy? wyartykułowano z kolei wiele interesujących uwag na temat polskiego społeczeństwa. Znaleźć w nim można następujący passus: „To, jacy jesteśmy zadecydowało o powstaniu i o dalszych losach «Solidarności». W przypadkach, w kuluarowych rozgrywkach, w cechach osobistych poszczególnych ludzi można znaleźć przyczynę poszczególnych wydarzeń, ale nie całego ich ciągu, czyli historii. Tym, którzy narzekają na charakter i politykę L. Wałęsy chcę przypomnieć, że każdy naród ma takiego wodza, jakiego zechce słuchać. W przypadku Wałęsy jest to prawda oczywista, ponieważ ten wódz pochodzi z wyboru. Nawet, jeśli przeskoczył płot strajkującej stoczni trochę w stylu «deus ex machina», to potem miliony ludzi potwierdziły gotowość złożenia swego losu w jego ręce. Działacze, którzy postępowali niezgodnie z oczekiwaniami ludzi zostali z «Solidarności» wyeliminowani. «Solidarność» podjęła taki model działania, jaki odpowiadał woli większości"75. Trudno nie zgodzić się z tą argumentacją oraz nie dostrzec, że wśród wyeliminowanych z władz "Solidarności" działaczy znaleźli się też twórcy "Skorpiona" i „Poza Układem”.

\section{Podsumowanie}

Pisma "Skorpion” i „Poza Układem” były autorskimi projektami Joanny Dudy-Gwiazdy, wokół której skupiła się grupa osób nastawionych opozycyjnie zarówno wobec władz komunistycznych, jak i wobec zorganizowanych pod szyldem Tymczasowej Komisji Krajowej podziemnych struktur Solidarności. Do grupy tej zaliczali się też działacze i sympatycy Solidarności Walczącej. Jak wspominał Marek Czachor: „Środowisko «Poza Układem» i «Solidarności Walczącej Trójmiasto» przechodziło w sposób ciągły jedno w drugie, w sposób sformalizowany i niesformalizowany. Nie sposób wyznaczyć ostrej granicy"76. Z racji powiązań z małżeństwem Gwiazdów środowisko to określano potocznie mianem "Gwiazdozbioru".

Choć w latach 1982-1986 ukazały się zaledwie trzy numery "Skorpiona” i dziesięć numerów „Poza Układem", a nakład obu tych pism był niewielki, były one bez wątpienia ważnym głosem tak zwanej niekonstruktywnej opozycji. Pisma finansowały swoją działalność z własnych środków i nie korzystały z pomocy finansowej TKK ani też (powstałego w 1985 roku) Funduszu Wydawnictw Niezależnych. Wydaje się zresztą, że raczej nie mogły na nią liczyć, gdyż jak wspominała Joanna Duda-Gwiazda: „Władze podziemia przyjęły strategię umacniania własnych wpływów, podkreślania władczych uprawnień, powiększania swojego podziemnego królestwa. Inicjatywy nie uzgodnione uważano za niesubordynację. Działania grup niezależnych od władzy podziemia traktowano podejrzliwie, jako obce, niemal wrogie. Tak przynajmniej było w regionie gdańskim"77. Właśnie dlatego ostrze publicystyki omawianych pism skierowane było zarówno w komunistów, jak i w TKK oraz w reprezentującą ją na terenie Gdańska Regionalną Komisję Koordynacyjną.

\footnotetext{
74. Ibidem.

75. Jacy jesteśmy?, "Poza Układem” 1986, nr 10, s. 8.

76. Relacja pisemna Marka Czachora z 2 czerwca 2020 (w zbiorach autora).

77. Gwiazdozbiór w "Solidarności", s. 296.
} 
Czasopisma "Skorpion” i „Poza Układem” adresowane były do czytelników wymagających i krytycznych wobec otaczającej ich rzeczywistości. W swojej publicystyce nierzadko poruszały tematy bardzo niewygodne dla solidarnościowego podziemia. Zamieszczane w nich teksty miały zwykle charakter polemiczny, a czasem wręcz ironiczny i okraszony niemałą dozą czarnego humoru ${ }^{78}$. Dzięki temu, że redakcje obu pism nie zajmowały się informacją bieżącą, publikowane w nich artykuły zachowywały aktualność przed długi czas. Ich lektura także dziś może być cenna dla badaczy historii podziemnej Solidarności, gdyż oprócz warstwy faktograficznej zawierają one interesujące przemyślenia na temat sytuacji społeczno-politycznej Polski w latach osiemdziesiątych. Za swoiste ideowe credo przyświecające działalności obu pism uznać można passus, który znalazł się w dziesiątym numerze "Poza Układem": "Nie można dążyć do zmiany rzeczywistości, poruszając się po omacku, wśród mitów, opierając się na cudzych sądach i fałszywych portretach, retuszowanych i podkolorowywanych ku pokrzepieniu serc, a dla zmylenia sojuszników i przeciwników"79. Zarówno "Skorpion”, jak i „Poza Układem" nie były sztampowymi gazetkami podziemnymi, a celem ich wydawania nie było w żadnym razie "krzepienie serc" tropionych przez bezpiekę działaczy i sympatyków Solidarności, lecz chłodna analiza rzeczywistości i formułowanie konstruktywnych pomysłów do dalszej działalności opozycyjnej. Co więcej, to właśnie na łamach tych pism pojawiły się chyba pierwsze krytyczne głosy, ostrzegające przed odchodzeniem podziemnej Solidarności od zasad demokracji i odrywaniem się jej kierownictwa od oczekiwań szeregowych członków i sympatyków związku.

Inna rzecz, że twórcy obu pism musieli zdawać sobie sprawę z faktu, że ich realny wpływ na krajową politykę był marginalny. Mimo to - powo- łując się na historię Wolnych Związków Zawodowych Wybrzeża - postulowali wytrwałą pracę u podstaw, stwierdzając przy tym, że: „Polityka nie dzieli się na wielką i małą, ale na skuteczną i nieudolną, uczciwą i nieetyczną. Nie należy się zrażać, że dostępna nam arena polityczna jest mała. Jeśli nawet nie uda nam się jej poszerzyć, ale nasza polityka będzie skuteczna i uczciwa to przyczyni się do politycznego rozwoju społeczeństwa we właściwym kierunku. Jeśli będziemy mieli dobre pomysły, dużo odwagi i konsekwencji oraz łut szczęścia może się zdarzyć, że przebijemy się ze swoim programem. Obok KPN-u, który dysponował najbardziej nośnym i jednoczącym hasłem niepodległości, który legitymował się świetnymi nazwiskami, dobrą organizacją i poligrafią, dużym i zasłużonym autorytetem, RMP utworzonym przez liczną grupę inteligentnych młodych ludzi, WZZ-ty Wybrzeża były najmniej liczącym się ugrupowaniem opozycyjnym. Mimo to, właśnie WZZ-tom udało się przebić ze swoim pomysłem na skalę masową"80. Trudno nie zgodzić się $\mathrm{z}$ tą oceną.

Choć z uwagi na niski nakład, ograniczony kolportaż i swój efemeryczny charakter oba pisma stanowiły niewielki margines bujnie rozwijającego się w latach osiemdziesiątych podziemnego ruchu wydawniczego, to na ich pożółkłych kartach można dziś znaleźć wiele frapujących przemyśleń, które wciąż pozostają inspirujące zarówno dla profesjonalnych historyków, jak i dla wszystkich czytelników zainteresowanych najnowszą historią Polski.

Na zakończenie warto wspomnieć, że Joanna i Andrzej Gwiazdowie w 1989 roku własnym sumptem wznowili wydawanie „Poza Układem”, które od tej pory przybrało postać miesięcznika o kilkutysięcznym nakładzie ${ }^{81}$. Druga edycja pisma ukazywała się do roku 1997 i także zasługuje na poszerzoną analizę historyczną.

\footnotetext{
78. Zob. m.in. Zwyciężymy!, "Poza Układem” 1986, nr 10, s. 8.

79. Jacy jesteśmy?, s. 8.

80. Polityka skuteczna, "Poza Układem” 1985, nr 6, s. 4-5.

81. Wybór artykułów z drugiej edycji pisma można znaleźć w książce: J. i A. Gwiazda, Poza układem. Publicystyka z lat 1988-2006, oprac. R. Okraska, Łódź 2008.
} 


\section{Bibliografia}

\section{Opracowania i publicystyka}

Błażejowska J., Papierowa rewolucja. Z dziejów drugiego obiegu wydawniczego w Polsce 1976-1989/1990, Warszawa 2010.

Borowski R., Tysiąc stron o seryjnym zabójcy Skorpionie, https:// www.trojmiasto.pl/wiadomosci/Pierwsza-taka-ksiazka-o-sprawie-Pawla-Tuchlina-ps-Skorpion-n140639.html.

Cecuda D., Leksykon Opozycji politycznej 1976-1989, Warszawa 1989.

Ciag dalszy Czarnobyla, "Solidarność Walcząca. Pismo organizacji Solidarność Walcząca oddział Trójmiasto" 1986, nr 20.

Chrząstek J., Jak powstał zespół „Bez Jacka”, http://bezjacka. art.pl/strona/historiabj/.

Czachor M., Uwagi o pismach SWT w Trójmieście, http://www. mif.pg.gda.pl/kft/SW/Uwagi_0_pismach_SWT_2020.pdf.

Czachor M., List otwarty do Pana Profesora Andrzeja Friszke członka Kolegium IPN, https://old.sw.org.pl/relacje/friszke.html. Czachor M., Marek Kubasiewicz otrzymał z IPN status pokrzywdzonego,

https://jozefdarski.pl/612-marek-kubasiewicz-otrzymal-z-ipn-status-pokrzywdzonego.

Droga do niepodległości. Solidarność 1980-2005, red. A. Borowski, Warszawa 2005.

Fic A., Drukarnia podziemna w Trójmieście w latach wojny jaruzelsko-polskiej, Gdynia 2005.

Friszke A., Rewolucja Solidarności 1980-1981, Kraków 2014. Holzer J., Leski K., Solidarność w podziemiu, Łódź 1990. Głos z podziemia. PU rozmawia z Kornelem Morawieckim, „Poza Układem" 1984, nr 3.

Gwiazda A., Nasza geopolityka, "Poza Układem” 1984, nr 4. Gwiazda J. i A., Poza układem. Publicystyka z lat 1988-2006, oprac. R. Okraska, Łódź 2008.

Gwiazda A., "Solidarność" - związek zawodowy, czy antykomunistyczny ruch niepodległościowy, "Poza Układem” 1984, nr 5. Gwiazda piołun, "Solidarność Walcząca. Pismo organizacji Solidarność Walcząca oddział Trójmiasto" 1986, nr 17.

Gwiazdozbiór w "Solidarności". Joanna i Andrzej Gwiazdowie w rozmowie z Remigiuszem Okraską, Łódź 2009.

Jacy jesteśmy?, „Poza Układem” 1986, nr 10.

Jankowska J., Portrety niedokończone. Rozmowy z twórcami "Solidarności" 1980-1981, wstęp i oprac. A. Friszke, Warszawa 2003. Kisielewski S., Czego oczekuję od "Solidarności", "Tygodnik Solidarność" 1981, nr 13.
Knoch K., Pisma liberalne w drugim obiegu w latach 1979-1990, Warszawa 2015.

Kołodziej A., Zwiercan R., 0 godność $i$ wolność. Po prostu... Solidarność Walcząca w Trójmieście w latach 1982-1990, Kościerzyna 2010.

"Konspira” czyli siedmiu wspaniałych, „Poza Układem” 1984, nr 7.

Kowalski J., Złodzieje słów ukradli nam porozumienie, „Poza Układem" 1984, nr 1.

Krajobraz po bitwie, "Poza Układem” 1984, nr 7.

Kryptonim 333. Internowanie Lecha Wałęsy w raportach funkcjonariuszy Biura Ochrony Rządu, wstęp i oprac. T. Kozłowski, G. Majchrzak, Chorzów 2012.

Kubasiewicz-Houée E., Bez prawa powrotu, Wrocław 2005. Lewica i prawica, „Poza Układem” 1984, nr 5.

Ludzie po obu stronach krat, "Poza Układem” 1984, nr 2.

Łopiński M., Moskit M., Wilk M., Konspira. Rzecz o podziemnej Solidarności, Paris 1984.

Mażewski L., Ustrojowopolityczny taran. Polityka NSZZ "Solidarność" a przemiany ustrojowe w PRL w latach 1980-1982, Warszawa-Radzymin 2017.

Modzelewska A., Struktury organizacyjne NSZZ "Solidarność" w latach 1980-1989, Kraków 2020.

Od Redakcji, "Skorpion” 1982, nr 2.

Olaszek J., Podziemne dziennikarstwo. Funkcjonowanie głównych pism informacyjnych podziemnej "Solidarności" w Warszawie w latach 1981-1989, Warszawa 2018.

Olaszek J., Rewolucja powielaczy. Niezależny ruch wydawniczy w Polsce 1976-1989, Warszawa 2015.

Polityka - owoc zakazany, "Poza Układem” 1985, nr 6.

Polityka skuteczna, "Poza Układem” 1985, nr 6.

Polak W., Wydawnictwo Alternatywy. Z dziejów gdańskiej poligrafii podziemnej, Gdańsk-Toruń-Bydgoszcz 2009.

Richard Nixon o odprężeniu realnym, "Poza Układem” 1984, nr 4. Solidarność podziemna 1981-1989, red. A. Friszke, Warszawa 2006.

Szczesiak E., Borusewicz. Jak runął mur. Rozmowy z liderem opozycji demokratycznej, legendą Sierpnia '80 oraz podziemia "Solidarności", pierwowzorem "Człowieka z żelaza", Warszawa 2005. Terlecki R., "Solidarność". Dekada nadziei 1980-1989, Warszawa 2010.

Wywiad z Andrzejem Gwiazdą dla "Kontaktów" (pismo nauczycieli), "Poza Układem” 1986, nr 9.

Zwyciężymy!, „Poza Układem” 1986, nr 10. 


\section{Źródła archiwalne}

Archiwum Zakładowe Instytutu Pamięci Narodowej w Gdańsku. AZ IPN Gd 73/57, Materiały dotyczące Marka Kubasiewicza.

\section{Źródła wywołane}

Relacje: Stefana Adamskiego, Magdaleny Czachor, Marka Czachora, Joanny Dudy-Gwiazdy, Andrzeja Gwiazdy, Karola Krementowskiego i Ewy Kubasiewicz-Houée.

\section{Abstrakt}

Artykuł opisuje podziemną działalność wydawniczą grupy osób skupionych wokół Joanny i Andrzeja Gwiazdów w latach osiemdziesiątych XX wieku oraz historię tworzonych przez nich pism "Skorpion" i „Poza Układem”. Autor opisuje genezę i funkcjonowanie obu pism, analizuje ich linię programową i przybliża treść wybranych artykułów. Tekst oparty jest na archiwalnych egzemplarzach pism i na relacjach osób zaangażowanych w ich powstawanie. To pierwsze opracowanie historyczne na ten temat, a także przyczynek do - przygotowywanej przez Piotra Brzezińskiego - biografii politycznej Joanny i Andrzeja Gwiazdów.

Słowa kluczowe: Gdańsk, lata osiemdziesiąte XX wieku, Solidarność, stan wojenny, podziemie wydawnicze w PRL, Joanna i Andrzej Gwiazdowie, Solidarność Walcząca Trójmiasto

\section{Abstract}

The article describes the underground publishing activities of an informal group gathered around Joanna and Andrzej Gwiazda in the 1980s and the history of the magazines they created: "Skorpion" and "Poza Układem" ("Outside the System"). The author describes the genesis and functioning of both magazines, analyses their programme and introduces the content of selected articles. The text is based on archival copies of the periodicals and on the accounts of people involved in the creation of them. This is the first historical study on the subject, as well as a contribution to the political biography of Joanna and Andrzej Gwiazda prepared by Piotr Brzeziński.

Keywords: Gdańsk, the 1980s, Solidarity, martial law, underground publishing in the Polish People's Republic, Joanna and Andrzej Gwiazda, Fighting Solidarity Trójmiasto

Piotr Brzeziński (ur. 1983) - historyk, pracownik Oddziałowego Biura Edukacji Publicznej IPN w Gdańsku. Autor i współautor książek: Zapomniani dygnitarze. Pierwsi sekretarze Komitetu Wojewódzkiego PPR/PZPR w Gdańsku w latach 1945-1990. Szkice biograficzne (2013); Pogrzebani noca. Ofiary Grudnia '70 na Wybrzeżu Gdańskim. Wspomnienia, dokumenty (2015); Zwijanie sztandaru Komitet Wojewódzki PZPR w Gdańsku w latach 1975-1990 (2019), Zbrodnia bez kary. Grudzień 1970 w Gdyni. Przebieg wydarzeń, represje, walka o prawdę, najdłuższy proces III RP (2020).

Piotr Brzeziński (b. 1983) is a historian, employee of the Department Office of Public Education of the Institute of National Remembrance in Gdańsk. He has published several books, including Zapomniani dygnitarze. Pierwsi sekretarze Komitetu Wojewódzkiego PPR/PZPR w Gdańsku w latach 1945-1990. Szkice biograficzne (2013); Pogrzebani noca. Ofiary Grudnia '70 na Wybrzeżu Gdańskim. Wspomnienia, dokumenty (2015); Zwijanie sztandaru Komitet Wojewódzki PZPR w Gdańsku w latach 1975-1990 (2019), and Zbrodnia bez kary. Grudzień 1970 w Gdyni. Przebieg wydarzeń, represje, walka o prawdę, najdłuższy proces III RP (2020). 